\title{
Gender Differences in Online Dating: What Do We Know So Far? A Systematic Literature Review
}

CONFERENCE PAPER · JANUARY 2016

READS

61

4 AUTHORS:

\section{Olga Abramova}

4 PUBLICATIONS 0 CITATIONS

SEE PROFILE

Hanna Krasnova

Universität Potsdam

40 PUBLICATIONS 422 CITATIONS

SEE PROFILE

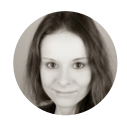

Annika Baumann

Humboldt-Universität zu Berlin

15 PUBLICATIONS 17 CITATIONS

SEE PROFILE

Peter Buxmann

Technical University Darmstadt

220 PUBLICATIONS 830 CITATIONS

SEE PROFILE 


\section{Gender Differences in Online Dating: What Do We Know So Far? A Systematic Literature Review}

\author{
Olga Abramova \\ Technische Universität Darmstadt \\ abramova@is.tu-darmstadt.de \\ Hanna Krasnova \\ Universität Bern \\ hanna.krasnova@iwi.unibe.ch
}

\author{
Annika Baumann \\ Humboldt-Universität zu Berlin \\ annika.baumann@wiwi.hu-berlin.de \\ Peter Buxmann \\ Technische Universität Darmstadt \\ buxmann@is.tu-darmstadt.de
}

\begin{abstract}
With millions of users worldwide, online dating platforms strive to assert themselves as powerful tools to find dates and form romantic relationships. However, significant differences exist in male and female use of this mate-matching technology with respect to motivation, preferences, self-presentation, interaction and outcomes. While existing research has routinely reported on gender differences in online dating, these insights remain scattered across multiple studies. To gain a systematic insight into existing findings, in this study we conduct a meta-review of existing research. We find that evolutionary theory generally holds true in online dating: Users still follow natural stereotypes when it comes to choosing a mate online. Physical attractiveness is the key criteria for men; while women, being much more demanding, prioritize socio-economic attributes when choosing a male partner. Together, our structured findings offer a deeper insight into the underlying dynamics of gender differences in online dating.
\end{abstract}

\section{Introduction}

Online dating industry is enjoying a booming success: $11 \%$ of U.S. adults have already used a dating platform or an app, and a whopping $23 \%$ of users admit to having met their spouse or a long-term companion online [61]. As such, online dating represents a place where connections can be formed and dissolved quickly at little cost to both sides, offline social norms are less pronounced, and gender stereotypes can be mitigated by the initial anonymity of the dating partners [70]. Making use of these affordances, both men and women readily embrace online dating channels in the search for a new companion, a short flirt, or even a long-term partnership. While statistics varies from country to country, and across different age groups, both men and women readily use popular dating platforms like Match.com, Yahoo Personals, eHarmony, and OkCupid, suggesting a strong interest of both parties in romantic interactions and connections [53].

Nonetheless, their preferences, behaviors and choices are likely to differ [9]. Indeed, in line with the evolutionary perspective on mating [15], men and women exhibit distinct selection criteria when it comes to choosing their mating partners - differences that have far-reaching implications for both scholars of social behavior as well as system designers. However, while a wave of studies investigating various userrelated aspects of online dating sites have captured a variety of gender-specific differences, these insights are scattered and do not provide a coherent picture of the state-of-the-art research available in this domain. To fill this gap, in this study we undertake a comprehensive review of existing empirical investigations to systematically summarize available knowledge in the area of gender differences in online dating.

This research is important for a number of reasons. On the theoretical side, our study will allow capturing the current research status quo, thereby helping to identify existing gaps open for future research. Furthermore, online-driven transformations in the mating behavior can be traced on the basis of our findings, allowing for better comparisons with the established knowledge from offline domain (e.g., [8]). From the managerial perspective, our study may empower platform providers in deciding on the genderspecific add-on features or special offers for the VIP platform areas common for such websites. On a more general level, by advancing knowledge in this domain this research may also contribute to a greater social good, since couples who meet via online channels have been shown be more satisfied and less likely to 
divorce, suggesting a favorable impact of online dating on the society at large [10].

\section{Theoretical Foundations}

Social role [16], self-construal [14] as well as evolutionary [9] theories have been often used to explain the differences in behavior and perceptions between men and women. In the dating context, particularly the evolutionary viewpoint is of critical importance, considering its focus on the choices of human species in the face of competition and search for limited reproduction-relevant opportunities. Originally formulated as a theory of sexual selection by [15], this perspective suggests that reproductive success is a key evolutionary aspiration of human species, with both men and women striving to achieve the best possible outcome in this domain.

A distinction between intrasexual and intersexual selection is often made. Intrasexual selection implies competition among representatives of the same sex for a desired mating access. Here, competing agents are expected to produce signals that are viewed as desirable by the members of the opposite sex. At the same time, intersexual selection implies preferential choice exerted by members of one sex group with regard to the representatives of the other group [9]. Conceptually representing two sides of the same phenomenon, the concepts of intra- and intersexual selection are closely related with the notion of parental investment [65]. According to this perspective, those who are expected to bear a higher parental investment in terms of nurturing and caring for potential offsprings are likely to be more selective with regard to their mating targets; at the same time, those who are less invested in the parental process will be less discriminative when choosing mating partners, striving to maximize "copulatory opportunities" ([9], p. 617). However, they will also face greater competition to achieve reproductive access, and will have to correspond to and present selection-relevant attributes to the "choosing" party.

Since in many species these are the females who have to overtake the largest share of the parental investment, they are also more likely to be more selective with regard to their choice of male mates. These choices will be dictated by the male ability to compensate for his lack of parental investment or by his ability to provide it. Indeed, material resources, earning potential, social status, psychological support, protection, and such traits as ambition and industriousness have been consistently shown to play a role in the female choice of male partners in offline settings [8].
Nonetheless, since modern society often equates reproduction access with monogamy, men also face costly choices. Hence, they are likely to emphasize health, "good genes", physical attractiveness, youth and other "female" qualities that may appear important for the fulfillment of the female reproductive function [8] [9].

So far, past research has provided empirical evidence for the existence of evolutionary-driven differences between male and female behaviors and perceptions in the offline context [8] [9]. At the same time, little systematic evidence exists on the gender differences in the modern context of online dating. Considering a growing independence of women and the rising emphasis on gender equality in the developed world [33], it might be possible that traditionally-assumed differences are no longer salient or at least undergo some degree of transformation. In the following, extant literature will be reviewed with regard to gender differences in online dating.

\section{Methodology}

Following the advice of Levy and Ellis [41] and Webster and Watson [67] we conducted a systematic literature review using the scientific databases ScienceDirect (154), EBSCOhost (211), Springer (791), Wiley Online Library (1091), Emerald Insights (47), JSTOR (205), ACM Digital Library (189), IEEE (97) and Google Scholar (12600) ${ }^{1}$ in combination with the keywords \{online dating OR digital dating OR dating website OR online mate OR internet dating OR internet romantic relationship OR online romance OR cyber flirting OR online love OR Match.com OR eHarmony\} and \{gender OR men OR women OR male OR female OR woman OR man OR sex differences $\}$. We focused on English language sources, included only published articles and excluded books from our review. No other filters were applied. To be relevant, papers needed to have online dating in the focus of their research. The evaluation of relevance was based on the title and abstract. In the next step, all articles initially evaluated as relevant were checked for the presence of gender-related empirical results using the in-text search in combination with the gender-marked keywords stated above. Additionally, we conducted a backward and forward search to look for further relevant articles. This procedure resulted in 69 relevant articles published between the years 1995 to 2015 . $73.19 \%$ of them were published in journals, $23.19 \%$ in conferences and the remaining two by the Pew

\footnotetext{
${ }^{1}$ Numbers in brackets reflect the overall initial number of resultant papers.
} 
Research Center [46] [61]. The most popular publication outlets included such journals as Computers in Human Behavior (8 studies), followed by Communication Research (3 studies). In terms of method, studies in our sample were based on surveys

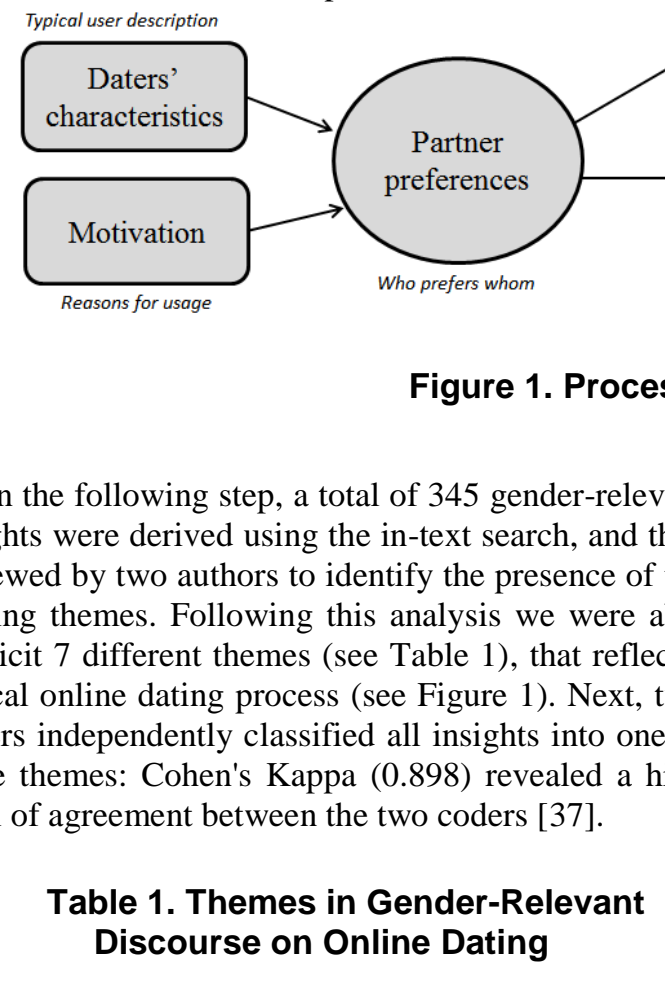

\begin{tabular}{|l|l|l|}
\hline Theme & Description & $\begin{array}{l}\text { \# of } \\
\text { insights } \\
\text { (share) }\end{array}$ \\
\hline $\begin{array}{l}\text { Daters' } \\
\text { Characteristics }\end{array}$ & $\begin{array}{l}\text { Characteristics of the user } \\
\text { population. }\end{array}$ & $\begin{array}{l}43 \\
(13.2 \%)\end{array}$ \\
\hline Motivation & $\begin{array}{l}\text { Motivational patterns of } \\
\text { users. }\end{array}$ & $\begin{array}{l}12 \\
(3.7 \%)\end{array}$ \\
\hline Preferences & $\begin{array}{l}\text { Preferences of users with } \\
\text { regard to mating choices. }\end{array}$ & $\begin{array}{l}149 \\
(45.9 \%)\end{array}$ \\
\hline Disclosure & $\begin{array}{l}\text { Information shared on the } \\
\text { profiles of users. }\end{array}$ & $\begin{array}{l}38 \\
(11.7 \%)\end{array}$ \\
\hline Misreporting & $\begin{array}{l}\text { Attributes misrepresented } \\
\text { by users. }\end{array}$ & $\begin{array}{l}35 \\
(10.8 \%)\end{array}$ \\
\hline \multirow{2}{*}{ Interaction } & $\begin{array}{l}\text { Dynamics of interaction } \\
\text { between users via private } \\
\text { messaging functionality. }\end{array}$ & $\begin{array}{l}46 \\
(14.2 \%)\end{array}$ \\
\hline \multirow{2}{*}{ Outcome } & $\begin{array}{l}\text { Offline consequences } \\
\text { resultant from online } \\
\text { dating. }\end{array}$ & $\begin{array}{l}22 \\
(6.8 \%)\end{array}$ \\
\hline
\end{tabular}

\section{Results}

Daters' Characteristics: Since the experience of online dating revolves around the people who

insights were derived using the in-text search, and then reviewed by two authors to identify the presence of the leading themes. Following this analysis we were able to elicit 7 different themes (see Table 1), that reflect a typical online dating process (see Figure 1). Next, two of these themes: Cohen's Kappa (0.898) revealed a high level of agreement between the two coders [37].

\section{Themes in Gender-Relevant}$$
\text { level of agreement between the two coders [37]. }
$$

(27), interviews (7), experiments (7), descriptive analysis (26) or other types of statistical analyses (9). Around $40 \%$ of articles focused on gender-related issues; student samples were present in only a small share of all articles in our sample (10\%). 
It appears that males are more active users of online dating sites: They use this service more [18] [19] [27] [31] [32] [35] [43] [46] [54] [55] and interact more on it [20] [31] [32] [43] [66]. One possible reason for this gender imbalance is that across numerous IT contexts men outnumber women [44].

Additionally, male users exhibit a positive attitude towards online dating, valuing its efficiency to meet people [44] [46], even though they might see those who use these service as desperate [46].

Motivation: Initial motives to engage in online dating are likely to play an important role in the subsequent process of mate selection. As such, sex differences in motivation are congruent with typical strategies of mating theory (see Table 3). When presented with a variety of opportunities, male users prefer short-term romantic relationships with low level of commitment [12] [27] [54]. In contrast, female users claim to be driven by such a non-romantic reason as finding friends [12] [27] [54] or a potential marriage partner [27], which, however, reveals inclination towards long-term relationships. Interestingly, these motivations are time-indifferent with studies dating 1995, 2008 and 2015 providing consistent results.

\section{Table 3. Motivation of Online Daters}

\begin{tabular}{|l|l|l|}
\hline \multicolumn{2}{|l|}{ Motivation to use } & Source \\
\hline Male & Short-term (e.g., sex or date) & {$\left[\begin{array}{l}{[12][27]} \\
{[54]}\end{array}\right.$} \\
\hline \multirow{2}{*}{ Female } & Long-term (e.g., friendship) & $\begin{array}{l}{[12][27]} \\
{[54]}\end{array}$ \\
\hline
\end{tabular}

Preferences: The process of conscious mateselection performed via online dating website implies a series of steps towards narrowing the pool of eligible candidates from many to one [26]. In line with the differences in motivational patterns established above, our review suggests a relatively clear picture regarding male and female preferences for certain characteristics sought in a partner (see Table 4).

While females appear to value but be more tolerant towards the appearance of the potential partner [32] [62] [68], men do not hesitate to state exact body type preferences [23] [31] [32] with thin and toned body types being most desired [23]. Indeed, physical attractiveness of a female appears to be a decisive criterion for male online daters [1] [4] [31] [32] [39] [47] [54] [68], corresponding to their search for female reproduction advantage.

With respect to age criterion there is a clear pattern for men to look for a younger [1] [7] [19] [32] [34] [36] [59] [69] or at least a same-age partner [59].
Moreover, these preferences are invariant to the age of a man.

\section{Table 4. Patterns of Partner Preferences of Online Daters}

\begin{tabular}{|c|c|c|c|}
\hline \multirow{2}{*}{$\begin{array}{l}\text { Characte- } \\
\text { ristics of } \\
\text { a partner }\end{array}$} & \multirow{2}{*}{$\begin{array}{l}\text { Direction of } \\
\text { preference } \\
\text { compared to } \\
\text { the self }\end{array}$} & \multicolumn{2}{|c|}{ Preferences of: } \\
\hline & & Male & Female \\
\hline \multirow{4}{*}{.0 } & $\begin{array}{l}\text { Up } \\
\text { (Higher) }\end{array}$ & & $\begin{array}{l}{[31][56]} \\
{[69]}\end{array}$ \\
\hline & Homophily & $\begin{array}{l}{[31][32]} \\
{[56]}\end{array}$ & $\begin{array}{l}{[31][32]} \\
{[56][60]}\end{array}$ \\
\hline & $\begin{array}{l}\text { Down } \\
\text { (Lower) }\end{array}$ & $\begin{array}{l}{[31][36]} \\
{[60]}\end{array}$ & \\
\hline & Importance & & [56] [69] \\
\hline \multirow{3}{*}{$\stackrel{\infty}{4}$} & Up (Higher) & & $\begin{array}{l}{[1][7]} \\
{[19][32]} \\
{[34][36]} \\
{[59][69]}\end{array}$ \\
\hline & Homophily & [59] & [59] \\
\hline & $\begin{array}{l}\text { Down } \\
\text { (Lower) }\end{array}$ & $\begin{array}{l}{[1][7][19]} \\
{[32][34]} \\
{[36][60]} \\
{[69]}\end{array}$ & $\begin{array}{l}{[1][7]} \\
{[19][59]} \\
{[69]}\end{array}$ \\
\hline \multirow{2}{*}{$\begin{array}{l}\overrightarrow{0} \\
\frac{000}{2} \\
\stackrel{ \pm}{I}\end{array}$} & $\begin{array}{l}\text { Up } \\
\text { (Higher) }\end{array}$ & & $\begin{array}{l}{[31][32]} \\
{[36][52]}\end{array}$ \\
\hline & $\begin{array}{l}\text { Down } \\
\text { (Lower) }\end{array}$ & $\begin{array}{l}{[31][32]} \\
{[52]}\end{array}$ & \\
\hline \multirow{3}{*}{ 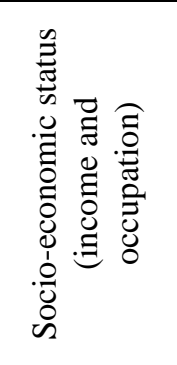 } & $\begin{array}{l}\text { Up } \\
\text { (Higher) }\end{array}$ & {$[32][68]$} & $\begin{array}{l}2][32] \\
{[50][54]} \\
{[68][69]}\end{array}$ \\
\hline & $\begin{array}{l}\text { Down or } \\
\text { no strong } \\
\text { preference }\end{array}$ & [2] [69] & \\
\hline & Importance & & $\begin{array}{l}{[2][31]} \\
{[32][47]} \\
{[68][69]}\end{array}$ \\
\hline \multirow{2}{*}{ 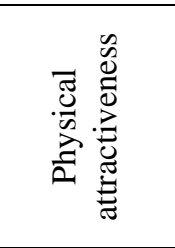 } & $\begin{array}{l}\text { Body type } \\
\text { preference }\end{array}$ & $\begin{array}{l}{[23][31]} \\
{[32]}\end{array}$ & \\
\hline & Importance & $\begin{array}{l}{[4][1][31]} \\
{[32][39]} \\
{[47][54]} \\
{[68]}\end{array}$ & $\begin{array}{l}{[32][62]} \\
{[68]}\end{array}$ \\
\hline \multirow{2}{*}{ 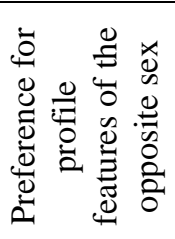 } & Photos & $\begin{array}{l}\begin{array}{l}{[4][18]} \\
{[36][69]}\end{array} \\
\end{array}$ & [18] [69] \\
\hline & Description & [18] & [36] \\
\hline
\end{tabular}

Quite on the contrary, female daters are better predisposed towards older male candidates [1] [7] [19] 
[32] [34] [36] [59] [69]. A more detailed investigation suggests that female age preference represents an inverted U-shape function of her own age. Starting with a strict preference for older partners, women broaden their preferred age ranges as they get older and show higher inclination towards homophily when they reach 25 years of age. However, aging women increasingly prefer younger partners [19].

Recent research argues for the derivative nature of age choice hypothesizing that preferences for "women's age are (partially) a function of male preferences for physical attractiveness, whereas female preferences for men's age are (partially) a function of female preferences for male socio-economic status" [59, p. 273]. In the modern society that values fitness and youth, youthful look is one of the key attributes of physical attractiveness. Coupled with the biological fact that female fertility is affected by age stronger than male fertility, this warrants the age choice of men [9] [15]. At the same time, females strongly prioritize socio-economic status [2] [31] [32] [47] [68] [69] when choosing a male partner, and, therefore, are more likely to prefer older and, hence, more financially mature male targets.

All in all, it is evident that female mating choice is congruent with the parental investment theory [65]. Women are pickier in specifying the type of partner they are looking for [17] [19] [23] [39] [63] [69]. The fact that family's material well-being may depend on male income [56] may explain strong preference of women to date wealthier men [2] [32] [50] [54] [68] [69]. According to our review, this also holds true for high earning women [50]. At the same time, men are more open and are ready to become acquainted with women with lower income [2] [69]. However, in general, both men and women prefer high-income partners over low-income partners [32] [68], which can be explained as an attempt to avoid dating for mercenary ends.

Further, a well-established positive relationship between socio-economic status and academic achievements [11] explains the fact that educational preferences follow the same gender patterns as socioeconomic status, and are much more critical for women [56] [69]. Higher academic degree of a man attracts women [31] [56] [69], while educational homophily is considered to be a good choice for both women [31] [32] [56] [60] and men [31] [32] [56].

All in all, men are much less demanding with respect to their mate's education and willingly contact women with a lower academic degree [31] [36] [60]. However, men are not attracted by women's intelligence when it surpasses their own [31].

Online daters' preferences for height follow "maletaller" norm [31] [32] [36] [52] for both cases, with preferences from the female side being more pronounced [52]. Tall men and short women, however, are more tolerant to the disparity in height, thereby maximizing their dating pool. This is in contrast to tall women and short men who try to adhere to socially recognizable standard [52].

Finally, men and women also have certain preferences when it comes to the information members of the opposite sex provide. While all daters who posted more photos have a greater chance to convince potential partners in their own attractiveness [18] [69], posting photos is especially relevant for the dating success of women. For them, the number of received messages is positively related to the number of photos they post [4] [18] [36] [69], once again indirectly proving the importance of physical attractiveness for men. In contrast, women prefer men to post longer self-descriptions [69] and perceive the candidate as more credible when rich media, such as video or audio, is used [39].

Disclosure: In order to allow for a match, both men and women present themselves to other participants of the online dating community, which implies a certain degree of disclosure (see Table 5).

It is observed that male daters disclose more than their female counterparts [22] [27] [43], even though their profiles are of rather standard, homogenous character, with a restricted range of information they choose to provide [35]. In line with the mating theory, demonstrating resources that are highly desired by members of the opposite sex, men tend to disclose status-related information like income and occupation [1] [2] [19] [24] [43] [47] or cars [35]. In the hope of moving the interaction to a more personal level, they are ready to provide photos [35], phone numbers [20] and sex-related information [35].

At the same time, women are more creative and multifarious in their self-presentations [35]. They are more likely to provide information about their children [35] [43], interests [68] as well as home and sex [19] [24]. Understanding the importance of their physical attractiveness for the mating success, women readily upload more photos than men [68] [69].

Textual analysis of the information provided in the "About me" section shows typical gender patterns, with men using more numerals and references to other people [24] and women using personal pronouns, positive emotion and spatial words as well as writing longer self-descriptions in general [19] [24]. However, no differences are observed in the use of frequent and tentative words [28]. All in all, the patterns of disclosure follow predictions of the evolutionary theory described above [9] [15]. 
Table 5. Disclosure Patterns of Online Daters

\begin{tabular}{|c|c|c|}
\hline \multicolumn{2}{|c|}{ Degree of disclosure } & Source \\
\hline \multirow{2}{*}{ Male } & $\begin{array}{l}\text { Disclose more information } \\
\text { about themselves }\end{array}$ & $\begin{array}{l}{[26][27]} \\
{[43]}\end{array}$ \\
\hline & $\begin{array}{l}\text { Reveal more homogeneous } \\
\text { information }\end{array}$ & {$[35]$} \\
\hline Female & $\begin{array}{l}\text { Provide more } \\
\text { heterogeneous information } \\
\text { and are more creative }\end{array}$ & {$[35]$} \\
\hline \multicolumn{2}{|c|}{$\begin{array}{l}\text { Type of information more likely to } \\
\text { be disclosed }\end{array}$} & Source \\
\hline \multirow{4}{*}{ Male } & $\begin{array}{l}\text { Status-related information } \\
\text { (income and occupation) }\end{array}$ & $\begin{array}{l}{[1][2][19]} \\
{[24][43]} \\
{[47]}\end{array}$ \\
\hline & Phone numbers & {$[20]$} \\
\hline & Photos & [35] \\
\hline & Sex and cars & [35] \\
\hline \multirow{5}{*}{ Female } & Information about kids & {$[35][43]$} \\
\hline & Desired age of a partner & {$[35]$} \\
\hline & Photos & [68] [69] \\
\hline & Interests & {$[68]$} \\
\hline & Home and sex & [19] [24] \\
\hline \multicolumn{2}{|c|}{$\begin{array}{l}\text { Type of information more likely to } \\
\text { be disclosed }\end{array}$} & Source \\
\hline \multirow[t]{2}{*}{ Male } & $\begin{array}{l}\text { Typically describe } \\
\text { themselves as average or } \\
\text { athletic and fit }\end{array}$ & [23] [43] \\
\hline & $\begin{array}{l}\text { Use more numbers and } \\
\text { social words in texts }\end{array}$ & {$[24]$} \\
\hline \multirow{3}{*}{ Female } & $\begin{array}{l}\text { Typically describe } \\
\text { themselves as small or } \\
\text { large and overweight }\end{array}$ & {$[23][43]$} \\
\hline & $\begin{array}{l}\text { Use longer texts for self- } \\
\text { description }\end{array}$ & [19] [24] \\
\hline & $\begin{array}{l}\text { Use more positive emotion } \\
\text { words, spatial words and } \\
\text { personal pronouns in texts }\end{array}$ & [19] [24] \\
\hline Both & $\begin{array}{l}\text { Use common and tentative } \\
\text { words }\end{array}$ & {$[48]$} \\
\hline
\end{tabular}

Misrepresentation: To achieve better matches, online daters are tempted to misrepresent certain desired attributes [38] (see Table 6). To prevent this, participants are encouraged to formally report the presence of falsified information through feedback mechanisms available on some platforms.

Both men and women report that they have faced instances of misreporting on online dating sites [61] suggesting that this behavioral tendency is rather common [45] [64]. However, different information is misrepresented by female and male daters (see Table
6). Aware of the importance of their physical attractiveness to men, females are more likely to use enhanced photographic material [29] [45] [57] [63] [68], and underreport their weight [13] [28] [30] [64] and age [13] (even though the latter is also common for men [28]). This way, female users are trying to advance themselves in comparison to other female contenders, rank higher in search listings, and, thereby, achieve better matches [9].

In contrast, men tend to rather emphasize their personal interests and assets [28] to gain a better hierarchical position in the competitive environment of online dating. This signaling behavior allows them access to a larger pool of females, who are generally seeking rather resource-rich males [65].

Since height is an attribute often psychologically associated with strength and status [9] and both short and tall women prefer taller men [31] [32] [36] [52], male users also have the tendency to overstate this characteristic on their profile [30] [57] [64] [68]. Furthermore, men have been found to misrepresent their current relationship status as well as the goals they want to achieve when using online dating services [28] [57] [68]. Possibly, they might do so to adapt their short-term focus to a rather long-term one of females [51], which is in line with the evolutionary theory [9] [15], since females have to invest more resources into the parental process [65].

Table 6. Misrepresentation Patterns of Online Daters

\begin{tabular}{|c|c|c|}
\hline $\begin{array}{l}\text { Information } \\
\text { on: }\end{array}$ & $\begin{array}{l}\text { Females are } \\
\text { more likely to } \\
\text { misrepresent: }\end{array}$ & $\begin{array}{l}\text { Males are more } \\
\text { likely to } \\
\text { misrepresent: }\end{array}$ \\
\hline \multirow[t]{2}{*}{ Age } & $\begin{array}{l}\text {...their age } \\
{[13] .}\end{array}$ & ...their age [28]. \\
\hline & \multicolumn{2}{|c|}{ No gender differences [30]. } \\
\hline Height & & $\begin{array}{l}\text {...their height [30] } \\
\text { [57] [64] [68]. }\end{array}$ \\
\hline $\begin{array}{l}\text { Physical } \\
\text { Attractiveness }\end{array}$ & $\begin{array}{l}\text {...their } \\
\text { physical } \\
\text { attractiveness } \\
{[29][45][57]} \\
{[63][68] .}\end{array}$ & $\begin{array}{l}\text {...their physical } \\
\text { attractiveness [20] }\end{array}$ \\
\hline Relationship & & $\begin{array}{l}\text {...their } \\
\text { relationships } \\
\text { status [57] [68] } \\
\text { and goals [28] } \\
\text { [57]. }\end{array}$ \\
\hline Weight & $\begin{array}{l}\text {...their weight } \\
{[13][28][30]} \\
{[64] .}\end{array}$ & $\begin{array}{l}\text {...their weight } \\
\text { [64]. }\end{array}$ \\
\hline General & $\begin{array}{l}\text {...themselves } \\
{[20] .}\end{array}$ & $\begin{array}{l}\text {...themselves } \\
\text { [25]. }\end{array}$ \\
\hline
\end{tabular}


Interaction: In terms of resulting interaction (see Table 7), there is a strong agreement in the literature that females receive more contacts by males who readily initiate a starting conversation [5] [18] [19] [20] [32] [36] [42] [54] [69]. Moreover, functionalityenabled ability to see who visited one' profile is particularly encouraging for men (e.g. as offered on Match.com, eHarmony, Parship, OkCupid, and others), who are more likely to use this feature to send messages to females who visited their profile [5]. In line with the above, males also receive significantly fewer replies and messages in general [5] [18] [19] [31] [36] [43], whereas females can expect a lot of reciprocation [18] [19] [31] [36] [54] [69]. In their interactions, women tend to send more general messages [69] as well as are more likely to carry on the communication [54]. Together, this suggests that males try to make use of the opportunity to have access to multiple females and are satisfied with a superficial character of such contacts. In contrast, women are rather picky in their decision of who might be their potential date [3]. Interacting with fewer male users, women show interest in creating more intimate and intensive conversations [54].

\section{Table 7. Interaction Patterns of Online Daters}

\begin{tabular}{|c|c|c|}
\hline $\begin{array}{l}\text { Types of } \\
\text { interaction }\end{array}$ & $\begin{array}{l}\text { Females are } \\
\text { more likely to: }\end{array}$ & $\begin{array}{l}\text { Males are more } \\
\text { likely to: }\end{array}$ \\
\hline Initiation & $\begin{array}{l}\text {...receive more } \\
\text { initial messages } \\
{[19][20] .}\end{array}$ & $\begin{array}{l}\text {...initiate contact } \\
\text { [5] [18] [19] [32] } \\
{[36][42][54]} \\
{[69] .} \\
\text {...receive more } \\
\text { initiations relative } \\
\text { to profile views } \\
{[20] .}\end{array}$ \\
\hline Reciprocation & $\begin{array}{l}\text {...receive a reply } \\
{[18][19][31]} \\
{[36][69] .}\end{array}$ & $\begin{array}{l}\text {...not receive a } \\
\text { reply [5] [18] [19] } \\
{[31] .}\end{array}$ \\
\hline General & $\begin{array}{l}\text {...receive more } \\
\text { messages [36] } \\
\text { [54] [69]. } \\
\text {...send more } \\
\text { messages [69]. } \\
\text {...carry on the } \\
\text { interaction [54]. }\end{array}$ & $\begin{array}{l}\text {...send more } \\
\text { messages [43]. } \\
\text {...receive fewer } \\
\text { messages [36] } \\
{[43] .} \\
\text {...participate in } \\
\text { more } \\
\text { communications } \\
{[18] .}\end{array}$ \\
\hline
\end{tabular}

Some characteristics, such as, for example, attractiveness or using only few self-references seem to increase the likelihood to receive a reply for both men and women [58]. Additionally, explicitly stated dating preferences [19] and a sexually-related talk [58] enhance the chances of reciprocation for female users. At the same time, lengthy messages enhance the chances for men to get a reply [58].

Outcome: In the final step of the online dating process (see Figure 1) a shift to the offline environment might take place. It appears that females are rather reluctant to meet other users face-to-face since they need more computer-mediated interaction compared to males before an actual meeting offline [20]. This might be connected to the circumstance that females are more likely to experience negative interactions on online dating sites [61], which is also supported by the evidence that females are more likely to tell others about their plan to meet with another user in the offline setting [6]. Even though one study reports higher first meeting rates for females [21], there is more evidence that both men and women tend to have a similar amount of first-date experiences offline using online dating platforms [27] [61].

The first face-to-face meeting is the point where the fit with a potential partner is evaluated: Here, females have higher drop-out rates in terms of their subsequent evaluation of their dating partner [49]. Again, this might suggest that men tend to focus on quantity, whereas females rather emphasize the "quality" of their dating partners [51] [65]. Overall, studies report contradictory findings that either more females [40] [54], more males [10] [27] or both [27] [61] have experienced a positive outcome in terms of various dating goals (e.g., long-term relationships or sexual relationship, with men reporting more sexual relationships [27]). Together, however, this evidence suggests that using online dating services can be beneficial for both, even though more research is needed to gain a better understanding of this dynamics.

\section{Concluding Remarks}

In a delicate IT-driven business of online dating, providers are becoming increasingly attentive to how users make their choices. Understanding behavioral patterns enables providers to select relevant offers, thereby helping to increase the matching rate - one of the main goals of these platforms. Responding to this demand, this study provides an exhaustive summary of gender differences in behavior and perceptions of online daters. By focusing on heterosexual dating process, our findings reveal how gender intersects with daters' characteristics, motivation, preferences, disclosure, misrepresentation, interaction and offline outcomes. We analyze singles' online dating behavior in line with the evolutionary approach. We observe that men are more active on online dating platforms. They 
are less choosy about partners and are more likely to be motivated by short-term romantic pleasure. While male online daters are attracted by physical appearance of a potential mate, female daters base their choices on male breadwinning abilities and give preference to socio-economic characteristics (income, occupation and education) over physical attractiveness. Although men disclose more readily, women lead in creativity and variety of information provided. However, both males and females are caught misrepresenting some of their information when creating their profiles. For example, digital enhancement of physical attractiveness is rather characteristic for female daters. At the same time, male users are more likely to falsify their relationships status and goals. Interacting on online dating platforms each party follows its conventional role: Men initiate more contacts, giving women a choice to reciprocate the attention and carry on the interaction. Regarding the outcome of online dating, gender differences remain unclear and offer an interesting venue for future research. Our study has several limitations: race-related and homosexual preferences were not in the scope of the current analysis. Moreover, cultural differences [15] were not considered, thus paving the way for further investigations.

\section{References}

[1] Alterovitz, S. S. R. and Mendelsohn, G. A., "Partner preferences across the life span: online dating by older adults", Psychology and aging, 24(2), 2009, p. 513.

[2] Anderson, R. C., and Klofstad, C. A. "For love or money? The influence of personal resources and environmental resource pressures on human mate preferences", Ethology, 118(9), 2012, pp. 841-849.

[3] Arnold, S. J. and Duvall, D. "Animal mating systems: a synthesis based on selection theory," American Naturalist, 1994, pp. 317-348.

[4] Bak, P. "Sex differences in the attractiveness halo effect in the online dating environment", Journal of Business and Media Psychology, 1, 2010, pp. 1-7.

[5] Bapna, R., Ramaprasad, J., Shmueli, G. and Umyarov, A., "One-way mirrors and weak-signaling in online dating: A randomized field experiment", International Conference on Information Systems (ICIS 2013): Reshaping Society Through Information Systems Design, 3, 2013, pp. 27482762.

[6] Blackhart, G. C., Fitzpatrick, J., and Williamson, J., "Dispositional factors predicting use of online dating sites and behaviors related to online dating", Computers in Human Behavior, 33, 2014, pp. 113-118.
[7] Burrows, K., "Age preferences in dating advertisements by homosexuals and heterosexuals: From sociobiological to sociological explanations", Archives of Sexual Behavior, 42(2), 2013, pp. 203-211.

[8] Buss, D. M., "Sex differences in human mate preferences: Evolutionary hypotheses tested in 37 cultures", Behavioral and Brain Sciences, 12, 1989, pp. 1-49.

[9] Buss, D.M., "The evolution of human intrasexual competition: Tactics of mate attraction", Journal of Personality and Social Psychology, 54(4), 1988, pp. 616628.

[10] Cacioppo, J. T., Cacioppo, S., Gonzaga, G. C., Ogburn, E. L. and VanderWeele, T. J., "Marital satisfaction and break-ups differ across on-line and off-line meeting venues", Proceedings of the National Academy of Sciences, 110(25), 2013, pp. 10135-10140.

[11] Caro, D. H., McDonald, J. T. and Willms, J. D. "Socioeconomic status and academic achievement trajectories from childhood to adolescence," Canadian Journal of Education/ Revue canadienne de l'éducation, 32(3), 2009, pp. 558-590.

[12] Clemens, C., Atkin, D., and Krishnan, A., "The influence of biological and personality traits on gratifications obtained through online dating websites", Computers in Human Behavior, 49, 2015, pp. 120-129.

[13] Close, A. G., and Zinkhan, G., "Romance and the Internet: The E-Mergence of Edating", Advances in Consumer Research, 31, 2004, pp. 153-157.

[14] Cross, S. E. and Madson, L.,"Models of the Self: SelfConstruals and Gender", Psychological Bulletin, 122(1), 1997, pp. 5-37.

[15] Darwin, C., The descent of man and selection in relation to sex, J. Murray, London, 1871.

[16] Eagly, A. H., Sex differences in social behavior: A social-role interpretation, Hillsdale, NJ: Erlbaum, Psychology Press, 2013.

[17] Feliciano, C., Robnett, B., and Komaie, G., "Gendered racial exclusion among white internet daters", Social Science Research, 38(1), 2009, pp. 39-54.

[18] Fiore, A. T., and Donath, J. S., "Homophily in online dating: when do you like someone like yourself?", In CHI'05 Extended Abstracts on Human Factors in Computing Systems, ACM, 2005, pp. 1371-1374.

[19] Fiore, A. T., Taylor, L. S., Zhong, X., Mendelsohn, G. A. and Cheshire, C., "Who's right and who writes: People, profiles, contacts, and replies in online dating", In hicss, IEEE, 2010, pp. 1-10.

[20] Gane, M., "Gender differences in online dating: An investigation of vulnerability and deception", Annual meeting of the American Sociological Association, 2005. 
[21] Gibbs, J. L., Ellison, N. B. and Heino, R. D., "Selfpresentation in online personals the role of anticipated future interaction, self-disclosure, and perceived success in Internet dating" Communication Research, 33(2), 2006, pp. 152-177.

[22] Gibbs, J. L., Ellison, N. B. and Lai, C. H., "First comes love, then comes Google: An investigation of uncertainty reduction strategies and self-disclosure in online dating" Communication Research, 2011, 0093650210377091.

[23] Glasser, C. L., Robnett, B. and Feliciano, C., "Internet daters' body type preferences: Race-ethnic and gender differences", Sex roles, 61(1-2), 2009, pp. 14-33.

[24] Groom, C. J. and Pennebaker, J. W., "The language of love: Sex, sexual orientation, and language use in online personal advertisements", Sex Roles, 52(7-8), 2005, pp. 447461.

[25] Guadagno, R. E., Okdie, B. M. and Kruse, S. A., "Dating deception: Gender, online dating, and exaggerated self-presentation", Computers in Human Behavior, 28(2), 2012, pp. 642-647.

[26] Günaydin, G., Selcuk, E., and Hazan, C. "Finding the one: A process model of human mate selection," Human bonding, 2013, pp. 103-131.

[27] Gunter, B., "Internet dating: A British survey", In Aslib Proceedings 60(2), Emerald Group Publishing Limited, 2008, pp. 88-98.

[28] Hall, J. A., Park, N., Song, H. and Cody, M. J., "Strategic misrepresentation in online dating: The effects of gender, self-monitoring, and personality traits", Journal of Social and Personal Relationships, 27(1), 2010, pp. 117-135.

[29] Hancock, J. T. and Toma, C. L., "Putting your best face forward: The accuracy of online dating photographs", Journal of Communication, 59(2), 2009, pp. 367-386.

[30] Hancock, J. T., Toma, C. and Ellison, N., "The truth about lying in online dating profiles", In Proceedings of the SIGCHI conference on Human factors in computing systems, ACM, 2007, pp. 449-452.

[31] Hitsch, G. J., Hortaçsu, A. and Ariely, D., "Matching and sorting in online dating" The American Economic Review, 2010a, pp. 130-163.

[32] Hitsch, G. J., Hortaçsu, A., and Ariely, D., "What makes you click? - Mate preferences in online dating", Quantitative marketing and Economics, 8(4), 2010b, pp. 393-427.

[33] Inglehart, R. and Norris, P. Rising tide: Gender equality and cultural change around the world. Cambridge University Press. 2003

[34] Kaufman, G. and Phua, V. C., "Is ageism alive in date selection among men? Age requests among gay and straight men in Internet personal ads", The Journal of Men's Studies, 11(2), 2003, pp. 225-235.

[35] Kisilevich, S. and Last, M., Exploring gender differences in member profiles of an online dating site across 35 countries, Springer-Verlag, Berlin, Heidelberg pp. 57-78, 2010.

[36] Kreager, D. A., Cavanagh, S. E., Yen, J. and Yu, M., "Where Have All the Good Men Gone?" Gendered Interactions in Online Dating, Journal of Marriage and Family, 76(2), 2014, pp. 387-410.

[37] Landis, J. R. and Koch, G. G. "The measurement of observer agreement for categorical data," Biometrics 33 (1), 1977, pp. 159-174.

[38] Landolt, M. A., Lalumière, M. L., \& Quinsey, V. L. (1995). "Sex differences in intra-sex variations in human mating tactics: An evolutionary approach," Ethology and Sociobiology, 16(1), 1995, pp. 3-23.

[39] Lee, L., Loewenstein, G., Ariely, D., Hong, J. and Young, J., "If I'm not hot, are you hot or not? Physicalattractiveness evaluations and dating preferences as a function of one's own attractiveness", Psychological Science, 19(7), 2008, pp. 669-677.

[40] Lever, J., Grov, C., Royce, T. and Gillespie, B. J., "Searching for love in all the "write" places: Exploring Internet personals use by sexual orientation, gender, and age", International Journal of Sexual Health, 20(4), 2008, pp. 233-246.

[41] Levy, Y., and Ellis, T. J. 2006. "A Systems Approach to Conduct an Effective Literature Review in Support of Information Systems Research," Informing Science 9 (1), 2006, pp. 181-212

[42] Lewis, K., "The limits of racial prejudice", Proceedings of the National Academy of Sciences, 110(47), 2013, pp. 18814-18819.

[43] Lin, K. H. and Lundquist, J., "Mate Selection in Cyberspace: The Intersection of Race, Gender, and Education”, American Journal of Sociology, 119(1), 2013, pp. 183-215.

[44] Liu, X., "Sociological Examination of People's Attitude Towards Online Dating" The annual meeting of the American Sociological Association Annual Meeting, San Francisco, 2009.

[45] Lo, S. K., Hsieh, A. Y. and Chiu, Y. P., "Contradictory deceptive behavior in online dating" Computers in Human Behavior, 29(4), 2013, pp. 1755-1762.

[46] Madden, M. and Lenhart, A., "Online dating: Americans who are seeking romance use the Internet to help them in their search, but there is still widespread public concern 
about the safety of online dating", Pew Internet \& American Life Project, 2006.

[47] McWilliams, S. and Barrett, A. E., "Online dating in middle and later life gendered expectations and experiences", Journal of Family Issues, 35(3), 2014, pp. 411-436.

[48] Nagarajan, M. and Hearst, M. A., "An Examination of Language Use in Online Dating Profiles", In ICWSM, 2009.

[49] Norton, M. I., Frost, J. H. and Ariely, D., "Less is more: the lure of ambiguity, or why familiarity breeds contempt", Journal of personality and social psychology, 92(1), 2007, p. 97.

[50] Ong, D. and Wang, J., "Income attraction: An online dating field experiment", Journal of Economic Behavior \& Organization, 111, 2015, pp. 13-22.

[51] Rhodes, G., Simmons, L. W. and Peters, M. "Attractiveness and sexual behavior: Does attractiveness enhance mating success?. Evolution and human behavior," 26(2), 2005, pp. 186-201.

[52] Salska, I., Frederick, D. A., Pawlowski, B., Reilly, A. H., Laird, K. T. and Rudd, N. A., "Conditional mate preferences: Factors influencing preferences for height", Personality and Individual Differences, 44(1), 2008, pp. 203215.

[53] Sautter, J. M., Tippett, R. M. and Morgan, S. P., "The social demography of internet dating in the United States*", Social Science Quarterly, 91(2), 2010, pp. 554-575.

[54] Scharlott, B. W. and Christ, W. G., "Overcoming relationship-initiation barriers: The impact of a computerdating system on sex role, shyness, and appearance inhibitions", Computers in Human Behavior, 11(2), 1995, pp. 191-204.

[55] Schmitz, A., Sachse-Thürer, S., Zillmann, D. and Blossfeld, H. P., "Myths and facts about online mate choice Contemporary beliefs and empirical findings", Zeitschrift für Familienforschung - Journal of Family Research, 23(3), 2011.

[56] Schmitz, A., Skopek, J., Schulz, F., Klein, D. and Blossfeld, H. P., "Indicating mate preferences by mixing survey and process-generated data. The case of attitudes and behaviour in online mate search", Historical Social Research/Historische Sozialforschung, 2009, pp. 77-93.

[57] Schmitz, A., Zillmann, D. and Blossfeld, H., "Do women pick up lies before men? The association between gender, deception patterns, and detection modes in online dating", Online Journal of Communication and Media Technologies, 3(3), 2013, pp. 52-73

[58] Schoendienst, V. and Dang-Xuan, L., "The Role of Linguistic Properties in Online Dating Communication-A
Large-Scale Study of Contact Initiation Messages", In PACIS, 2011, p. 169.

[59] Skopek, J., Schmitz, A. and Blossfeld, H. P., "The gendered dynamics of age preferences-Empirical evidence from online dating", Zeitschrift für Familienforschung Journal of Family Research, 23(3), 2011.

[60] Skopek, J., Schulz, F. and Blossfeld, H. P., "Who contacts whom? Educational homophily in online mate selection”, European Sociological Review, 2010, jcp068.

[61] Smith, A. and Duggan, M., "Online dating \& relationships", Pew Internet \& American Life Project, 2013.

[62] Sritharan, R., Heilpern, K., Wilbur, C. J. and Gawronski, B., "I think I like you: Spontaneous and deliberate evaluations of potential romantic partners in an online dating context", European Journal of Social Psychology, 40(6), 2010, pp. 1062-1077.

[63] Toma, C. L. and Hancock, J. T., "Looks and lies: The role of physical attractiveness in online dating selfpresentation and deception", Communication Research, 37(3), 2010, pp. 335-351.

[64] Toma, C. L., Hancock, J. T. and Ellison, N. B., "Separating fact from fiction: An examination of deceptive self-presentation in online dating profiles", Personality and Social Psychology Bulletin, 34(8), 2008, pp. 1023-1036.

[65] Trivers, R.L., Parental investment and sexual selection. Sexual selection and the descent of man, Aldine de Gruyter, New York, pp. 136-179, 1972.

[66] Valkenburg, P. M. and Peter, J., "Who visits online dating sites? Exploring some characteristics of online daters", CyberPsychology \& Behavior, 10(6), 2007, pp. 849-852.

[67] Webster, J., and Watson, R. T. "Analyzing the past to prepare for the future: Writing a Literature Review," MIS Quarterly, 26(2), 2002, pp. 13-23.

[68] Whitty, M. T., "Revealing the 'real'me, searching for the 'actual'you: Presentations of self on an internet dating site", Computers in Human Behavior, 24(4), 2008, pp.17071723.

[69] Xia, P., Jiang, H., Wang, X., Chen, C. and Liu, B., "Predicting user replying behavior on a large online dating site", In Proceedings of 8th international AAAI conference on weblogs and social media, 2014.

[70] Žakelj, T., "Internet dating and respectable women: Gender expectations in an untraditional partnership and marriage market-the case of Slovenia", Sociologija, 56(1), 2014, pp. 5-21. 